\title{
ÇORUM ÜÇKÖY KÖYÜ CAMİi்: MİMARİ VE SÜSLEME ÖZELLİKLERİ
}

Çiğdem KARAÇAY $Y^{1}$

Atıf/O: Karaçay, Ç. (2019). Çorum Üçköy köyü camii: mimari ve süsleme özellikleri. Hitit Üniversitesi Sosyal Bilimler Enstitüsü Dergisi, 12(2), 521-538. doi: 10.17218/hititsosbil.608720

Özet: Bu makale, Çorum merkeze $40 \mathrm{~km}$. uzaklıkta bulunan ve bulunduğu köyün ismi ile bilinen Üçköy Köyü Camii'nin mimari ve süsleme özelliklerini Sanat Tarihi metodolojisi ile tanıtmayı ve benzer örneklerle karşılaştırarak yapının Anadolu Türk mimarisindeki yerini saptamayı amaçlamaktadır. Bu bağlamda Çorum Valiliği’nden gerekli izinlerin alınmasının ardından Üçköy Köyü Camii yerinde incelenmiştir. Köy merkezinde bulunan caminin inşa kitabesi bulunmamaktadır. Minare kaidesi üzerinde yer alan onarım kitabesine göre 1897 yılında bakımdan geçirilmiştir. Yapı, kareye yakın dikdörtgen planlı bir harim ile kuzeyindeki son cemaat yeri ve son cemaat yerinin batısındaki minareden oluşmaktadır. Cami dıştan kırma çatı, içten düz ahşap tavan ortasına bağdadi kubbe yerleştirilen örtü sistemine sahiptir. İç mekânda oldukça sade bir süsleme programı görülür. Kubbenin örtü sisteminde sembolik bir unsur olarak yer alması Ege Bölgesi, Marmara Bölgesi ve Doğu Karadeniz Bölgesi'nde dini ve sivil mimaride yaygındır. Ancak bu bölgelerde bağdadi kubbeli yapıların iç mekânlarında yoğun bir süsleme programı olduğu görülmektedir. Çorum Üçköy Köyü Camii ise tezyinat açısından olabildiğine sade harimi ile bağdadi kubbeli yapıların Orta Karadeniz Bölgesi'nde mütevazı bir örneğini temsil etmektedir.

Anahtar Kelimeler: Çorum, Üçköy Köyü, cami, bağdadi, sembolik kubbe

\section{Çorum Üçköy Village Mosque: Architectural and Decoration Features}

Citation/@: Karaçay, Ç. (2019). Çorum Üçköy village mosque: architectural and decoration features. Hitit University Journal of Social Sciences Institute, 12(2), 521-538. doi: 10.17218/hititsosbil.608720

Abstract: This article aims to introduce the architectural and decoration features of Üçöy Village Mosque, located $40 \mathrm{~km}$. from Çorum downtown area and named after the village, by employing Art History methodology and to compare such characteristics with similar examples in order to identify the standing of the structure in the Anatolian Turkish architecture. In this context, Üçköy Village Mosque has been visited and studied on-site after getting necessary permits from Çorum Governorate. Constructed at the center of the village, the mosque lacks any epitaph concerning its construction. According to the restoration epitaph present on the base of the minaret, the mosque has been restored in 1897. The structure is formed by an almost square shaped rectangular prayer place and the narthex to the north thereof and the minaret to the west of the narthex. The mosque's covering system features an exterior hipped roof, an interior flat wooden ceiling and a lath and plaster dome in-between. A rather plain decoration program can be seen at the indoor space. Presence of the dome at the covering system as a symbolic element is a prevalent feature at both religious and civil architecture at Aegean Region, Marmara Region and Eastern Black Sea Region. However, the indoor spaces of the structures with lath and plaster domes observed at said regions are observed to have extensive decoration programs. Çorum Üçköy Village Mosque, on the other hand, represents a modest example of the structures with lath and plaster domes at the Central Black Sea Region by virtue of its prayer place as plain as possible in terms of decoration.

Makale Geliş Tarihi: 21.8.2019_ Makale Kabul Tarihi: 14.12.2019

1 Dr. Öğr. Üyesi, Hitit Üniversitesi, Güzel Sanatlar, Tasarım ve Mimarlık Fakültesi, Resim Bölümü, cigdemkaracay@hitit.edu.tr, http://orcid.org/0000-0000-0000-0000 
Keywords: Çorum, Üçköy Village, mosque, lath and plaster, symbolic dome

\section{GİRIŞ}

Cami, Çorum il merkezine bağlı Üçköy Köyü, Köy içi Mevkii’nde bulunmaktadır. Çorum merkeze $40 \mathrm{~km}$ uzaklıktadır. Bulunduğu köyün ismi ile Üçköy Köyü Camii olarak bilinen yapının inşa kitabesi olmadığı için ne zaman ve kimin tarafından inşa ettirildiği bilinmemektedir. Eser, Ankara Kültür ve Tabiat Varlıklarını Koruma Kurulu'nun 9.4.1983 tarih ve A-4245 sayılı kararıyla tescillenmiştir. Bugün doğa koşullarının olumsuz etkisinin görüldüğü camide bir imam görevlidir ve halen ibadete açıktır. Çorum Üçköy Köyü Camii'nde gerekli incelemeleri yapabilmek için öncelikle Çorum Valiliği’nden izin alınmış, ardından yapı yerinde incelenmiştir².

Bu çalışma, Osmanlı Dönemi dini mimari örneklerinden Çorum Üçköy Köyü Camii'ni; plan, örtü sistemi, malzeme, mimari ve süsleme özellikleri açısından tanıtmayı ve fotoğraflarla belgeleyerek, benzer yapılar içerisindeki yerini belirtmeyi amaçlamaktadır. Ayrıca Çorum Üçköy Köyü'nde bulunan bu caminin ilk defa ele alınacak olması çalışmaya özgünlük kazandırmaktadır.

\section{2. ÜÇKÖY KÖYÜ CAMIII MİMARİ ÖZELLİKLERİ}

Köy merkezinde yer alan ve bir avlu içerisinde bulunan cami, kareye yakın dikdörtgen planlı bir harim ile kuzeyindeki son cemaat yeri ve son cemaat yerinin batısındaki minareden oluşmaktadır (Fotoğraf 1). Yapının inşa kitabesi bulunmamaktadır. Minare kaidesi üzerinde dört satırlık sülüs hatlı manzum onarım kitabenin okunuşu şöyledir ${ }^{3}$ :

- Cem' olur ehl-i Mü'min eyler niyaz

- Salât-1 hamsede kılınır namâz

- Hayr ile yâd olunur nâmı

- Paşazâde Ali Edhem eyledi ihyâ sene 1315

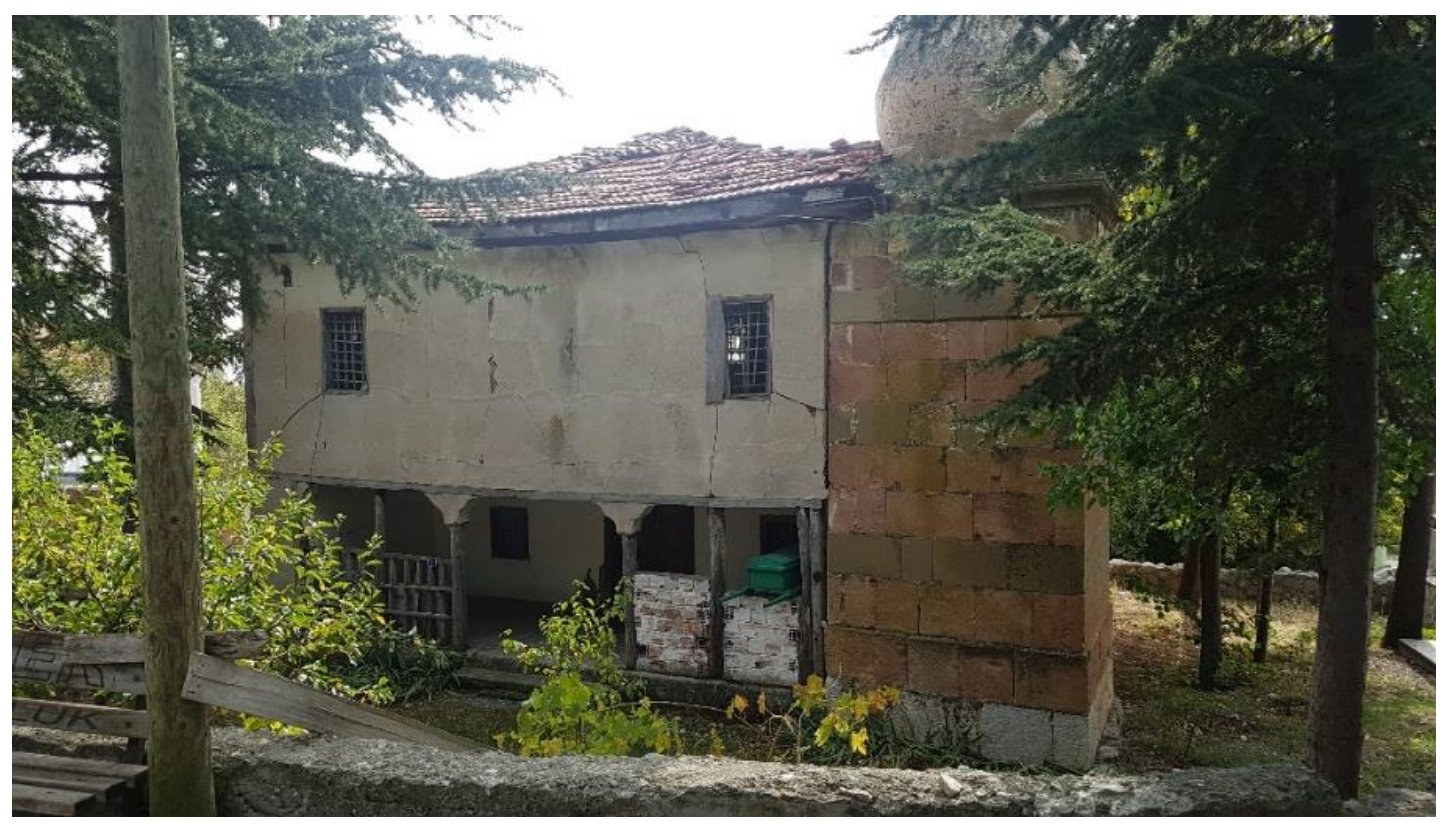

Fotoğraf 1. Üçköy Köyü Camii, kuzeyden genel görünüş, Ekim, 2018, Çiğdem Karaçay

\footnotetext{
2 Çorum Üçköy Köyü Camii'nin varlığından haberdar olmamı sağlayan Sayın Sabri Çiçekçi’ye teşekkür ederim. ${ }^{3}$ Kitabeyi okuyan ve transkripsiyonu yapan Hitit Üniversitesi İlahiyat Fakültesi Öğretim Görevlisi Sayın Sema Kılıç’a teşekkür ederim.
} 
Kitabenin tarih veren son satırına göre yapı H. 1315/M. 1897 yılında Ali Paşa tarafından bakımdan geçirilmiştir ${ }^{4}$. Cami, kuzey ve kuzeybatı yönünde ihata duvarıyla çevrilmiş bir bahçeye sahiptir. Avluya kuzeybatıdaki ahşap kapıdan girilmektedir. Hafif meyilli bir arazi üzerine inşa edilen cami, kuzey-güney doğrultusunda diştan dişa 8.90 m. x 13.90 m. ölçülerinde boyuna dikdörtgen planlıdır. Kuzeyinde son cemaat yeri ve son cemaat yerinin batısında minare yer almaktadır (Çizim 1). İçerde, düz ahşap tavan ortasında bağdadi teknikle yapılmış kubbesi vardır. Son cemaat yerinin üst katı kadınlar mahfili olarak düzenlenmiştir. Son cemaat yerinin üstünde, kadınlar mahfilinin doğu-batı doğrultusunda uzanması ön yüzü iki katlı kılmaktadır. Yapıda temel ve duvarlar moloz taş, duvar köşeleri kesme taştır. Cepheleri sıvalıdır. Ancak bazı kesimlerde sıvalar dökülmüş, bazı yerlerde yeniden sıva yapılmıştır (Fotoğraf 2). Yapı alaturka kiremitli kırma çatı ile örtülmüştür. Çatı dört yönde ahşap saçaklıdır.

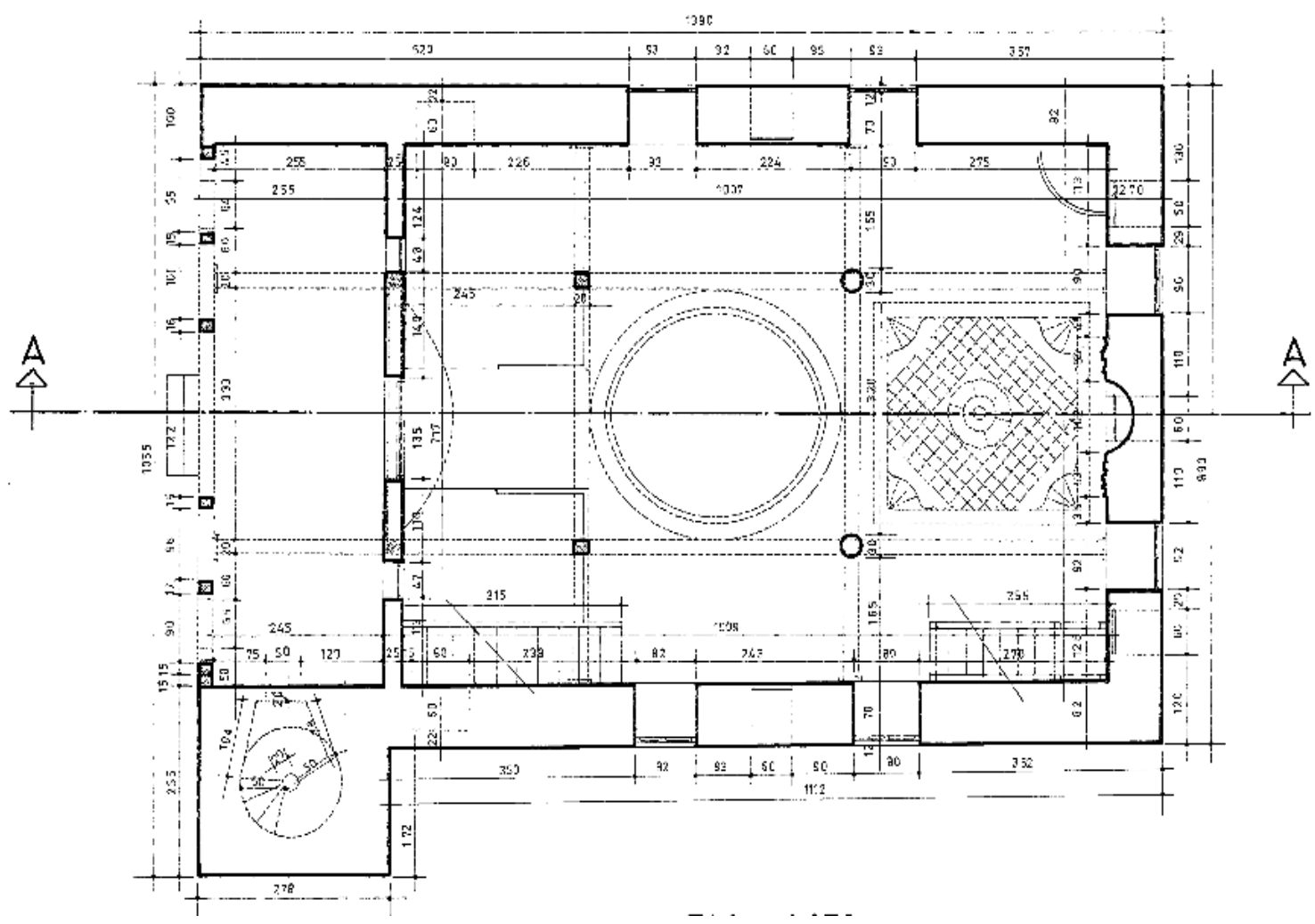

Çizim 1. Üçköy Köyü Camii, plan, Ocak, 2002, Vakıflar Genel Müdürlüğü arşivi

\footnotetext{
${ }^{4}$ Hurufat kayıtlarında caminin bakımdan geçirildiği 1897'den daha erken tarihe rastlanmaktadır. H. 1259/M. 1844 tarihine ait belge, Ücköy, Üçut Mevkii ve Ortaca Karyesinden oluşan büyük bir divan köyündeki camiye imam olarak atanan İsmail oğlu Hacı Mustafa Efendi'nin, Padişah beratıyla imamlık görevini sürdürürken çocuksuz olarak vefat etmesi üzerine, yerine Hüseyin oğlu Hüseyin Efendi'nin atanmasına dairdir. Cumhurbaşkanlığı Devlet Arşivleri, Belge no: EV.MKT.CHT154/112. Belgeye ulaşmam konusundaki yardımları ve belgenin transkripsiyonu için Vakıflar Genel Müdürlüğü Kültür ve Tescil Daire Başkanı Sayın Mevlüt Çam'a teşekkür ederim.
} 


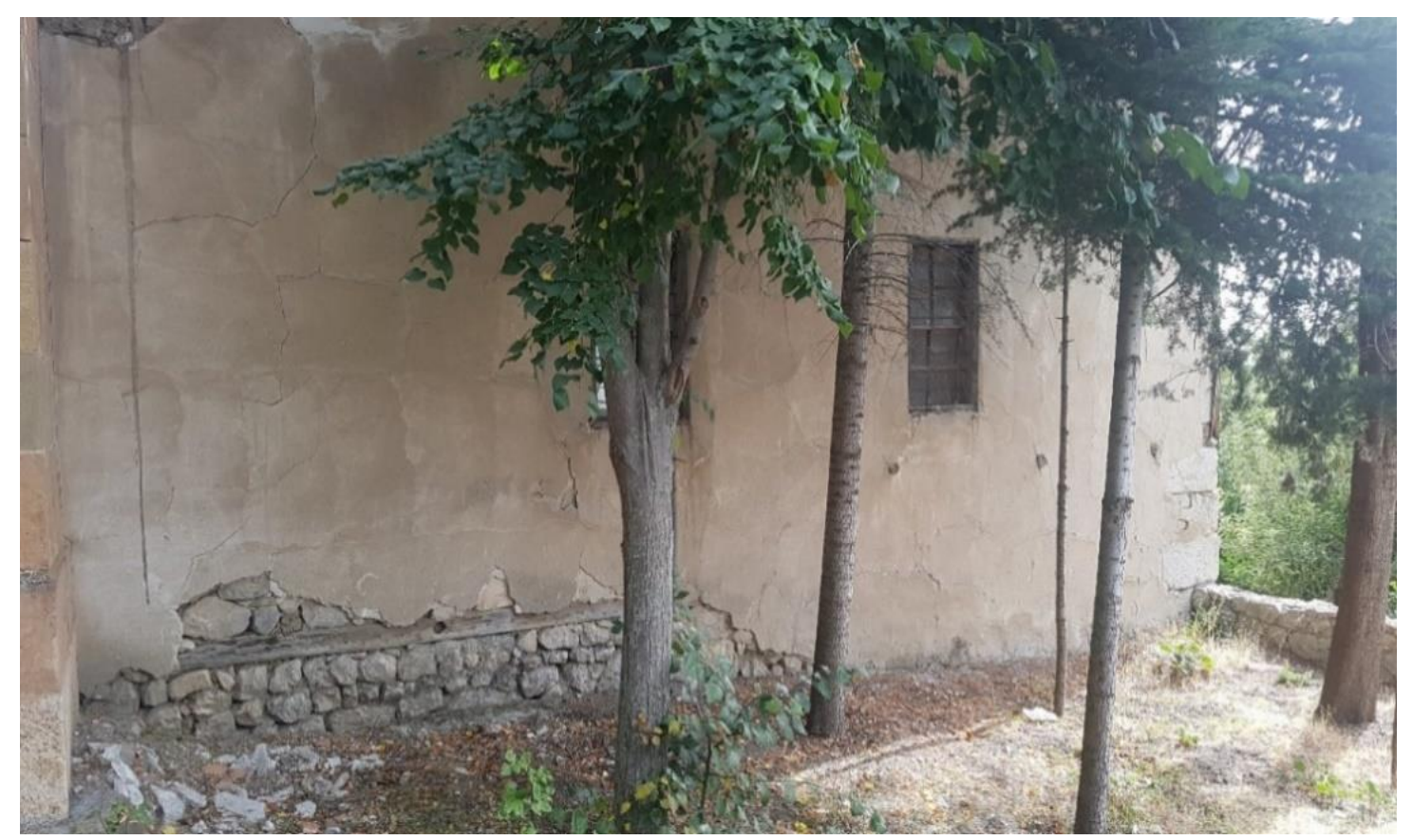

Fotoğraf 2. Üçköy Köyü Camii, batı cephe, Ekim, 2018, Çiğdem Karaçay

Minare, harimin kuzeybatı köşesindedir (Fotoğraf 3). Minare kaidesinde yer alan onarım kitabesine göre yapıya 1897 yılında eklenmiştir5 (Fotoğraf 4). Kesme taştan yapılan kare planlı kaide, harim duvarı ile aynı seviyede ve cepheyle bitişiktir. Ancak batı duvarı ile kaynaşmamaktadır. Kare kaide üzerine armudi pabuçla silindirik gövdeye geçilmektedir. Tuğla malzemenin kullanıldığı silindirik gövde tek şerefelidir. Pabucun bitiminde ve şerefe altında birer bilezik bulunmaktadır.

Yapı dıştan yalın bir görünüme sahiptir. Pencereler iki sıralıdır. Pencere sayıları düzensizdir. Caminin doğu ve batı cephesinde üçer, güney cephesinde beş, kuzey cephesinde ise dört pencere açıklığı bulunmaktadır. Doğu ve batı cephelerde üst sırada bir, alt sırada iki pencere, güney cephede üst sırada üç, alt sırada iki pencere düşey dikdörtgen biçimde yer almaktadır. Pencereler basit camekânlı ve ahşap kanatlıdır. Kuzey cephede üst sırada iki, alt sırada iki pencere vardır. Üst sırada ahşap kanatlı ve ahşap parmaklıklı pencereler düşey dikdörtgen biçimdedir. Alt sıra pencereler kare biçimli olup, harime giriş kapısının iki yanına simetrik olarak konumlanmıştır (Fotoğraf 5).

\footnotetext{
5 Cumhurbaşkanlığı Devlet Arşivlerinde H. 1313/M. 1895 tarihli belge, Amasya sancağına bağı Üçöy karyesinde bulunan ve deprem dolayısıyla yıkılan hanesinin inşası için yardım talep eden Mehmet'in arzuhali gönderildiğinde gereğinin yapılması hususundadır. Tarih: H-08.03.1313, Yer bilgisi, 420-6. Bahsi geçen depremde caminin de zarar gördüğü ve belgede belirtilen tarihten iki yıl sonra 1897 senesinde yapının onarılarak minarenin eklendiği anlaşılmaktadır.
} 


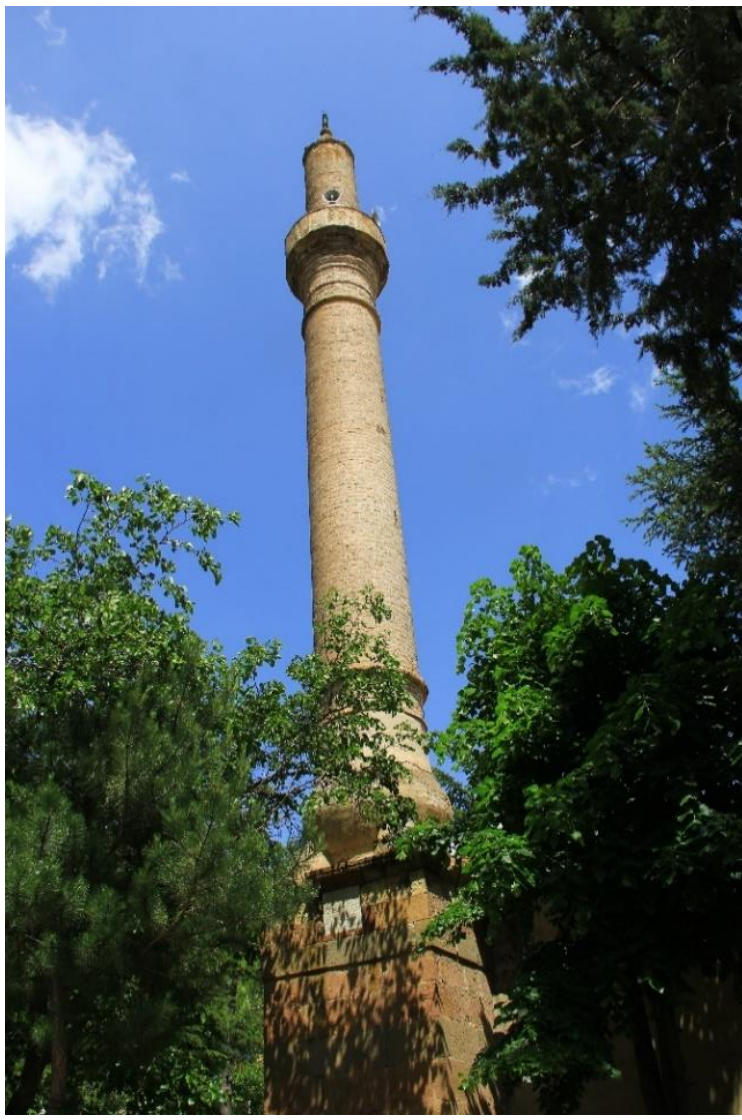

Fotoğraf 3. Üçköy Köyü Camii, kuzeybatı cephe, minare, Mayıs, 2018, Sabri Çiçekçi

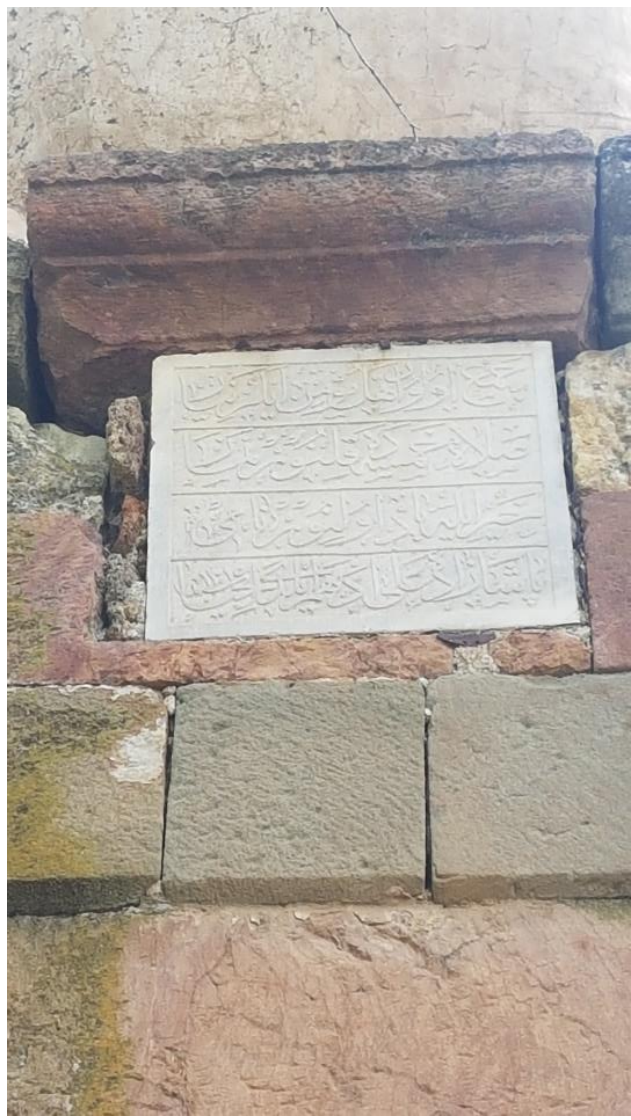

Fotoğraf 4. Üçköy Köyü Camii, minare kaidesinde yer alan mermer onarım kitabesi, Ekim, 2018, Çiğdem Karaçay

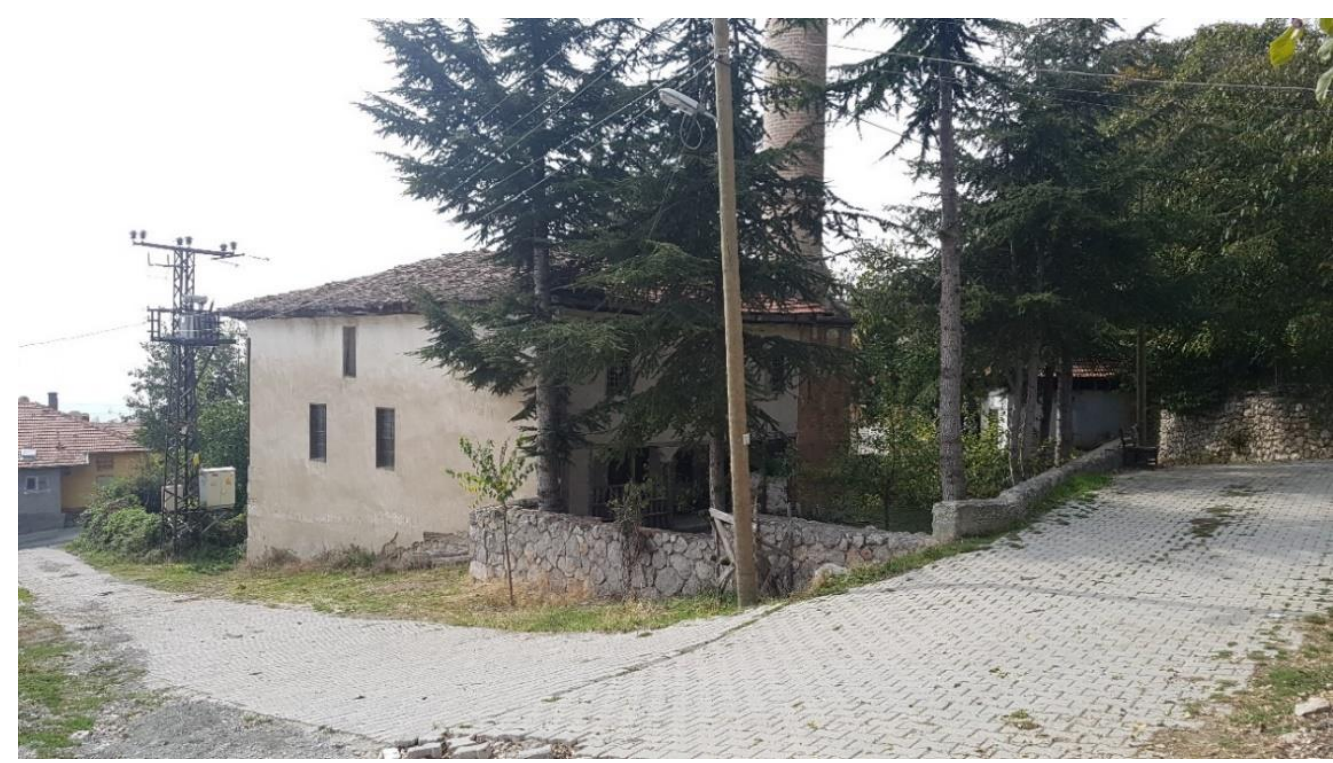

Fotoğraf 5. Üçköy Köyü Camii, kuzey ve doğu cephe, Ekim, 2018, Çiğdem Karaçay 
Yapının kuzey cephesinde, doğu-batı doğrultusunda uzanan enine dikdörtgen planlı son cemaat yeri bulunmaktadır. İçten düz ahşap tavanla örtülen son cemaat revakını beş ahşap direk taşımaktadır. Bu direklerden dört tanesi serbest, bir tanesi duvara bitişiktir. Doğu kısımda, ahşap direkler arasına ahşap korkuluk yerleştirilmiş, batı kısımda ise ahşap direkler arası sonradan yarı yüksekliğe kadar tuğla ile örülmüştür. Son cemaat yerinin doğu ve batı kenarları kapalıdır (Fotoğraf 1).

Avludan harime, mihrap eksenindeki yarım daire kemerli ve çift kanatlı kapıyla girilmektedir. İç mekân, cephelere açılan altlı üstlü toplam 15 pencereden 1 şı almaktadır. Bu pencerelerden, güneyde üst sırada dizilen üç pencere ile doğu ve batıda üst sırada yer alan birer pencere içerden alçı şebekelidir. Bu alçı şebekelerde pencere kemerleri yarım daire formludur.

Harim, düz ahşap tavan ve merkezde dört adet sütun ile desteklenen bağdadi kubbe ile örtülüdürø. Ahşap örtü sistemi içinde bağdadi kubbe ahşap tavanın merkezine yerleştirilmiştir. Harimin kubbeyle örtülü bölümün dişında kalan kısımlar dört yönde ahşap düz tavanla örtülmüştür (Fotoğraf 6).

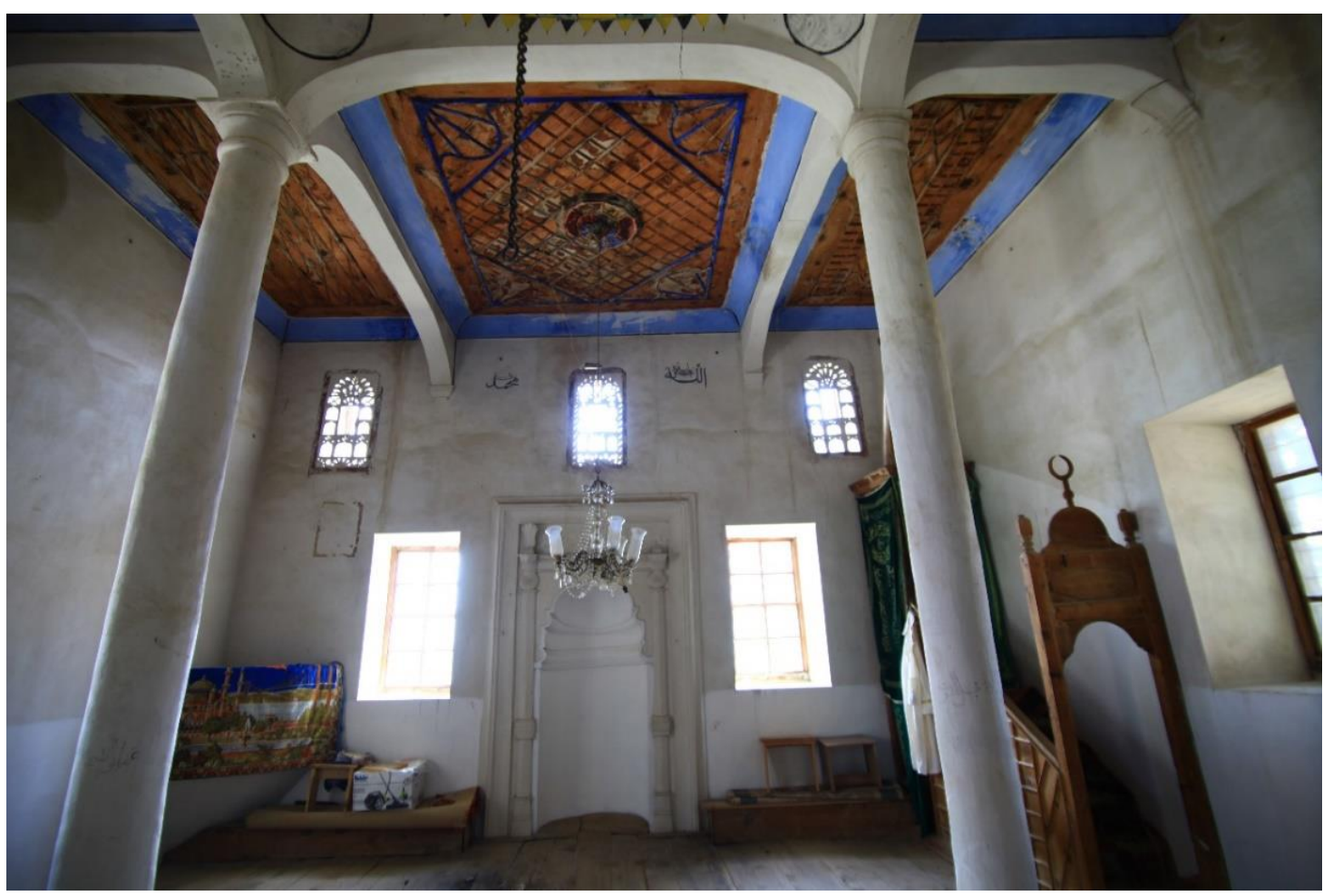

Fotoğraf 6. Üçköy Köyü Camii, harim, Mayıs, 2018, Sabri Çiçekçi

${ }^{6}$ Sütunlar ahşaptır. Ancak mihrap tarafında yer alan iki sütun sonradan alçı ile sıvanmıştır. 


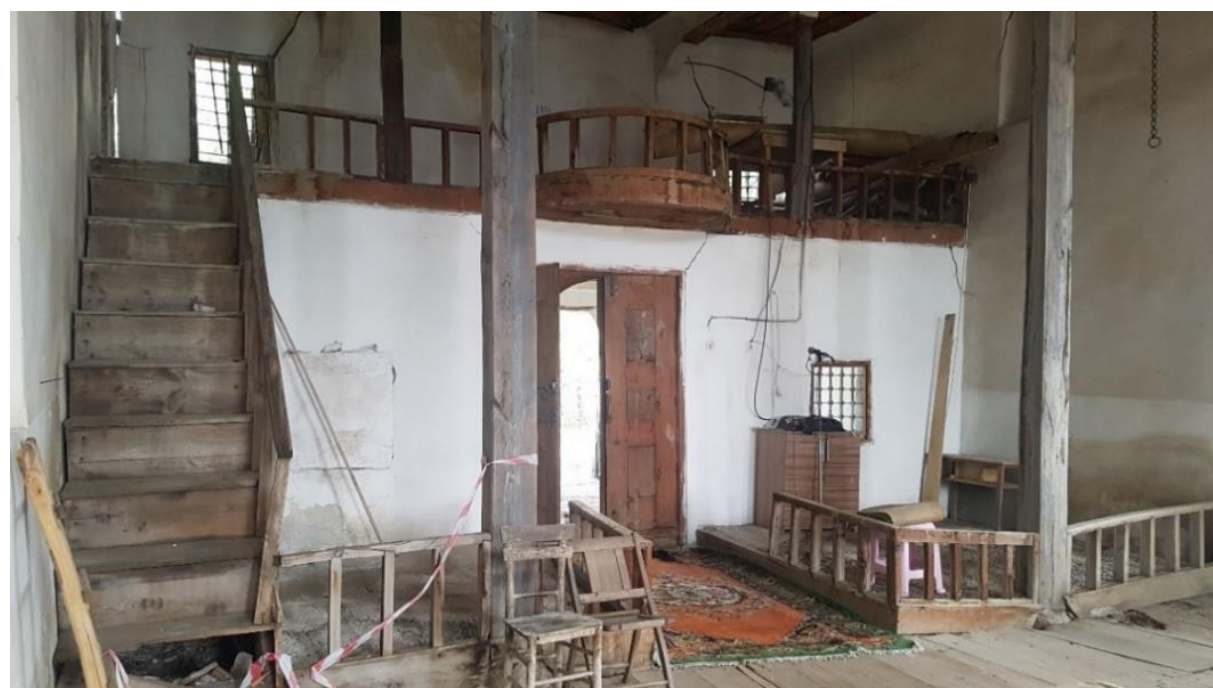

Fotoğraf 7. Üçköy Köyü Camii, kuzey cephe, mahfil, Ekim, 2018, Çiğdem Karaçay

Harimin kuzey tarafı mahfil olarak düzenlenmiştir (Fotoğraf 7). Ahşap mahfilin alt kısmı üç bölüme ayrılmıştır. Mihrap mihveri olan orta bölüm harime girişi sağlarken, doğu ve batı taraf korkuluklarla çevrili mahfil kısmı olarak tertip edilmiştir. Ahşap mahfil katına, harimin kuzeybatısındaki 11 basamaklı ahşap merdivenle çıkılmaktadır. Son cemaat mekânı üzerine düzenlenen mahfil, harim tarafında dört köşeli iki ahşap direk üzerine oturmaktadır. Korkulukları ahşap olan mahfilin orta bölümü güneye doğru bir yay şeklinde çıkıntı yapmaktadır. Mahfilin doğu ve batı kısmında birer niş yer almaktadır. Minareye çıkış, mahfilinin batı kısmındaki yarım daire kemerli kapıdan sağlanmaktadır. Kapı kemerinin kilit noktasında daire içerisinde "Mâşâllâh" yazmaktadır (Fotoğraf 8).

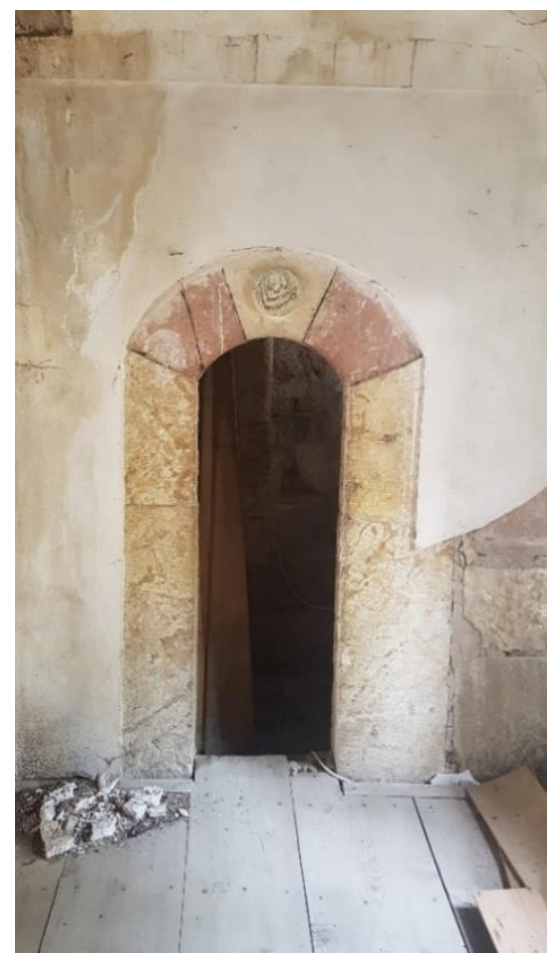

Fotoğraf 8. Üçköy Köyü Camii, minareye çıkış kapısı, Ekim, 2018, Çiğdem Karaçay

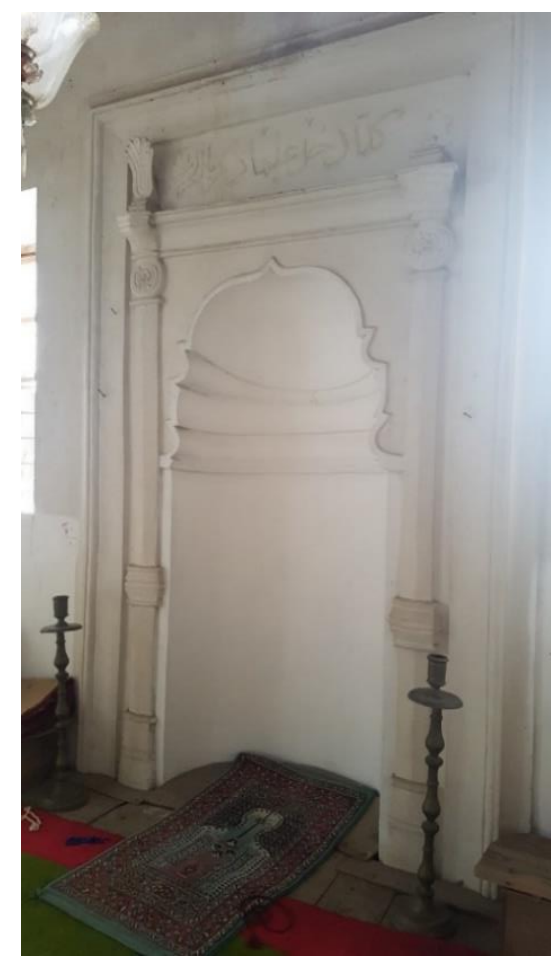

Fotoğraf 9. Üçköy Köyü Camii, mihrap, Ekim, 2018, Çiğdem Karaçay 
Mihrap, kıble duvarı ortasında, kuzey girişi aksında konumlanmıştır (Fotoğraf 9). İki yanda pilastır görünüm ile sınırlandırılmıştır. Alçı mihrap; çerçeve, köşelik, kavsara, niş ve sütuncelerden meydana gelmektedir. Dikdörtgen çerçeve içerisine alınmış mihrap nişi kaş kemerli ve yarı dairesel kesitlidir. Yivsiz istiridye kabuğu şeklini andıran kavsara tezyinatsızdır. Alınlık bölümü, dikdörtgen yazı çerçevesi ihtiva etmektedir. Çerçevede, Âl-i İmrân Suresinin 37. Ayetinin, "Küllemâ dehale aleyhâ Zekeriyya'l-Mihrâbe" kısmı yazılıdır7. Mihrabın iki yanında Üçköy Köyü Camii'ne vakfedilmiş iki adet kitabeli şamdan yer almaktadır (Fotoğraf 10). H. 1318/M. 1900 tarihli pirinç şamdanlarda "Devletlû Osmanlı Hazinedar Ustanın Bendelerinden Beşir Ağa'nın Vakfıdır" şeklinde kayıt vardır (Fotoğraf 11).

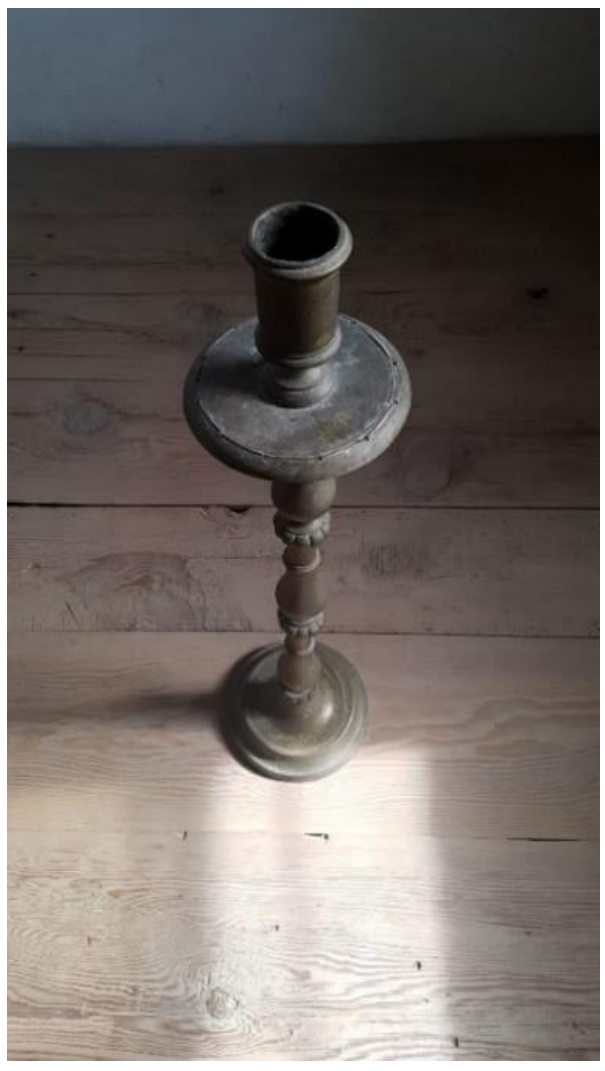

Fotoğraf 10. Üçköy Köyü Camii, kitabeli pirinç şamdan, Ekim, 2018, Çiğdem Karaçay

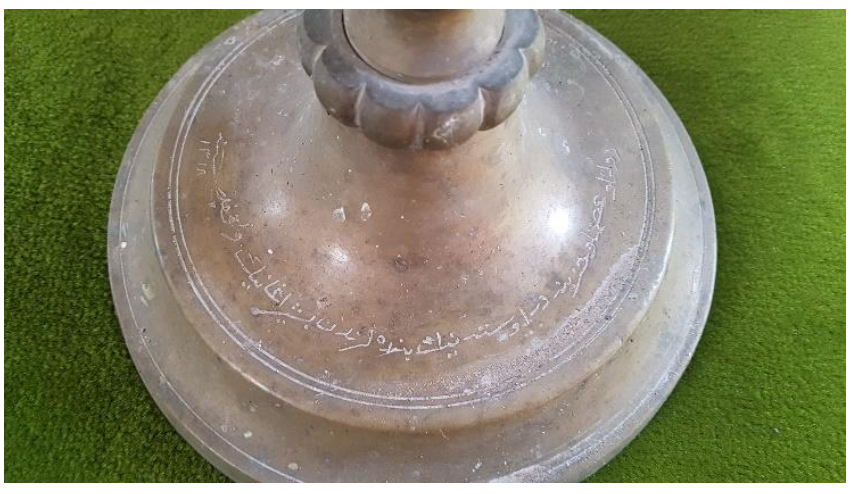

Fotoğraf 11. Üçköy Köyü Camii, kitabeli pirinç şamdan detay, Ekim, 2018, Çiğdem Karaçay

Güney cephenin batı kenarında minber yer alır. Minber tek yüzlüdür. Minberin girişi yarım daire kemerlidir. Kapı alınlığı boş olup köşe topuzlarının ortasında ahşaptan bir taç vardır. Taht kısmı dört ahşap sütuna binen ahşap bir külahla örtülmüştür (Fotoğraf 12). Güney cephenin doğu kenarında duvara bitişik yapılmış, ahşap korkuluklu vaiz kürsüsü yer almaktadır (Fotoğraf 13).

${ }^{7}$ Manası, "Zekeriyya Meryem’in bulunduğu mihraba her girdiğinde, ....." şeklindedir. 


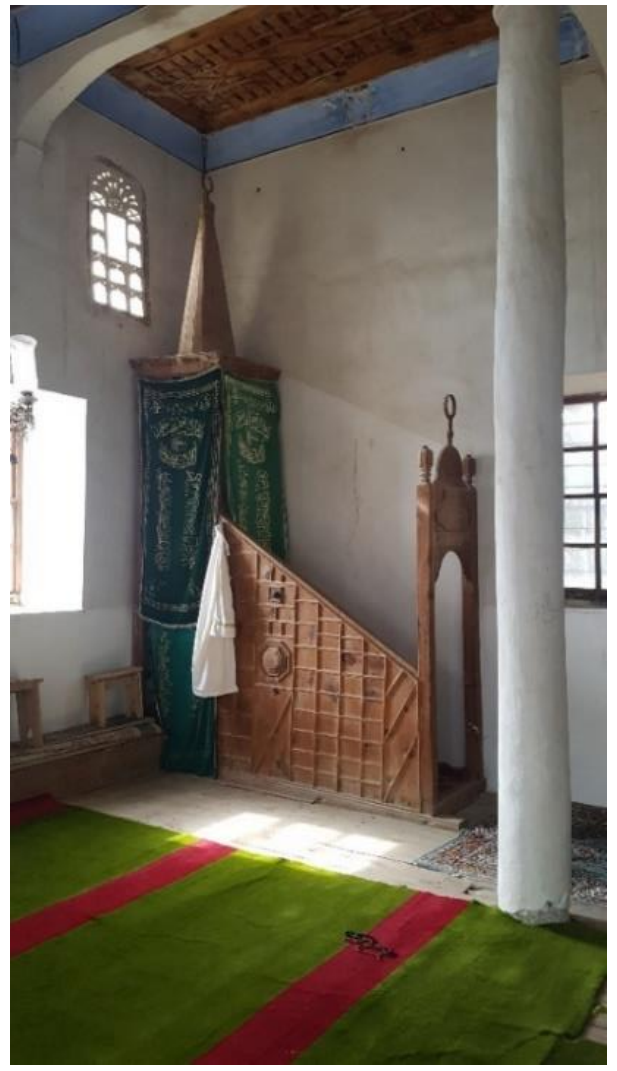

Fotoğraf 12. Üçköy Köyü Camii, minber, Ekim, 2018, Çiğdem Karaçay

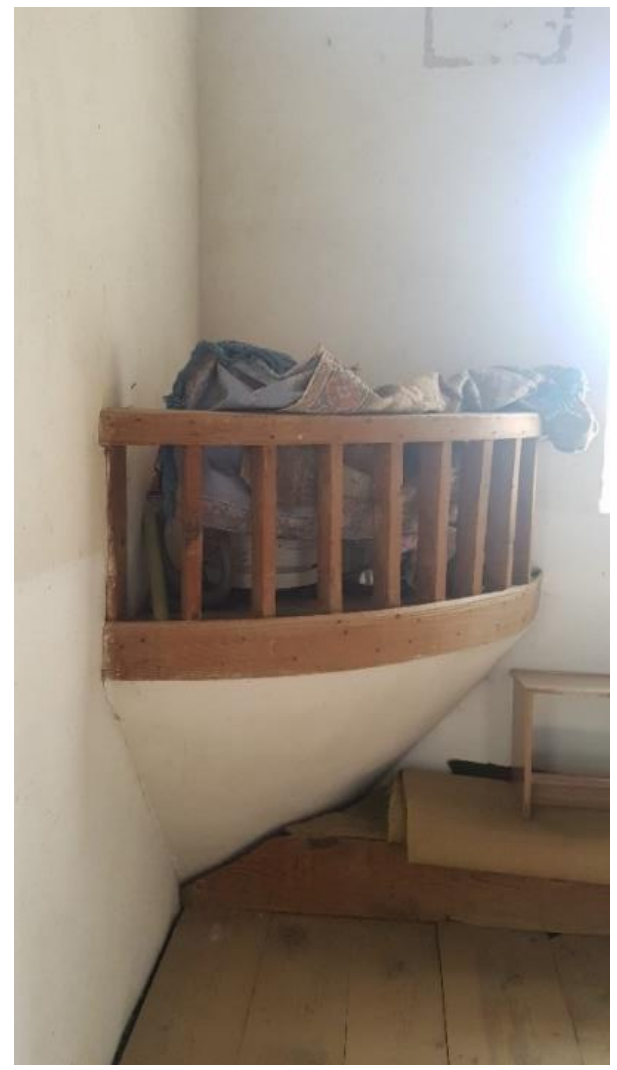

Fotoğraf 13. Üçköy Köyü Camii, vaiz kürsüsü, Ekim, 2018, Çiğdem Karaçay

\section{3. ÜÇKÖY KÖYÜ CAMİI SÜSLEME ÖZELLİKLERİ}

Üçköy Köyü Camii'nin süsleme programı genel itibariyle sadedir. Caminin süslemelerini ahşap, kalem işi ve alçı süsleme olmak üzere üç grupta incelemek mümkündür. Süslemeler harim tavanında yoğunlaşmaktadır. Harim tavanında, bağdadi kubbede kalem işi ve alçı süsleme, tavanın geri kalan kısmında ise çıtakâri teknikli süslemeler göze çarpmaktadır. Ahşap tavanın merkezinde yer alan bağdadi kubbe dekoratif unsur olarak karşımıza çıkmaktadır. Merkezi kubbenin göbeğinde, taç yapraklı çiçek motifi ile onu çevreleyen stilize lale ve karanfil motiflerinden oluşan alçı madalyon yer almaktadır. Madalyonun etrafı siyah bordür ile belirginleştirilmiştir. Sarı renkli sekiz adet şerit, merkezdeki kubbeden, kubbe eteğini çepeçevre kuşatan bordür sırasına uzanmaktadır. Kubbe eteğini çevreleyen alçı bordürde, beyaz, siyah, sarı ve yeşil renklerle tasvir edilen kare ve üçgen şekilli motiflerle geometrik karakterli bir tezyinat oluşturulmuştur. Bağdadi kubbenin pandantiflerinde etrafı siyah kontur ile belirginleştirilmiş yazı madalyonları yer almaktadır. Ancak, zamanla silik bir görünüm almasından dolayı yazılar okunamamaktadır (Fotoğraf 14). Kubbenin dışında tavanın geri kalan kısmı çıtalı ahşap tavandır. Merkezde yer alan bağdadi kubbenin güney tarafinda mihrap önü bölümü ile kubbenin kuzeyinde yer alan kısım, kubbe ile eşdeğer büyüklükte bir alanı kaplayan birer kare tabla, kubbenin batı ve doğu kanadı ise üçer adet dikdörtgen tabla halinde düzenlenmiştir. Mihrap önü bölümünün tavan süslemeleri bu alanı diğer bölümlerden farklı kılmaktadır (Fotoğraf 15). Bu kısımdaki kare tabla eşkenar dörtgenlerle süslenmiş olup ortada bir göbek ve göbeğin ortasında çıtakâri altı kollu bir yıldız ile tezyin edilmiştir. Kare tablanın dört köşesinde çıtakâri yelpaze motifleri yer almaktadır. Yelpaze motifleri ve kare tablanın dörtkenarı mavi renk ile vurgulanmıştır. Kubbenin 
kuzey kısmı ile doğu ve batı kanatları ise sade bir tezyinatta, baklava dilimi, ince ve uzun dikdörtgen şekilli motiflerle süslenmiştir.

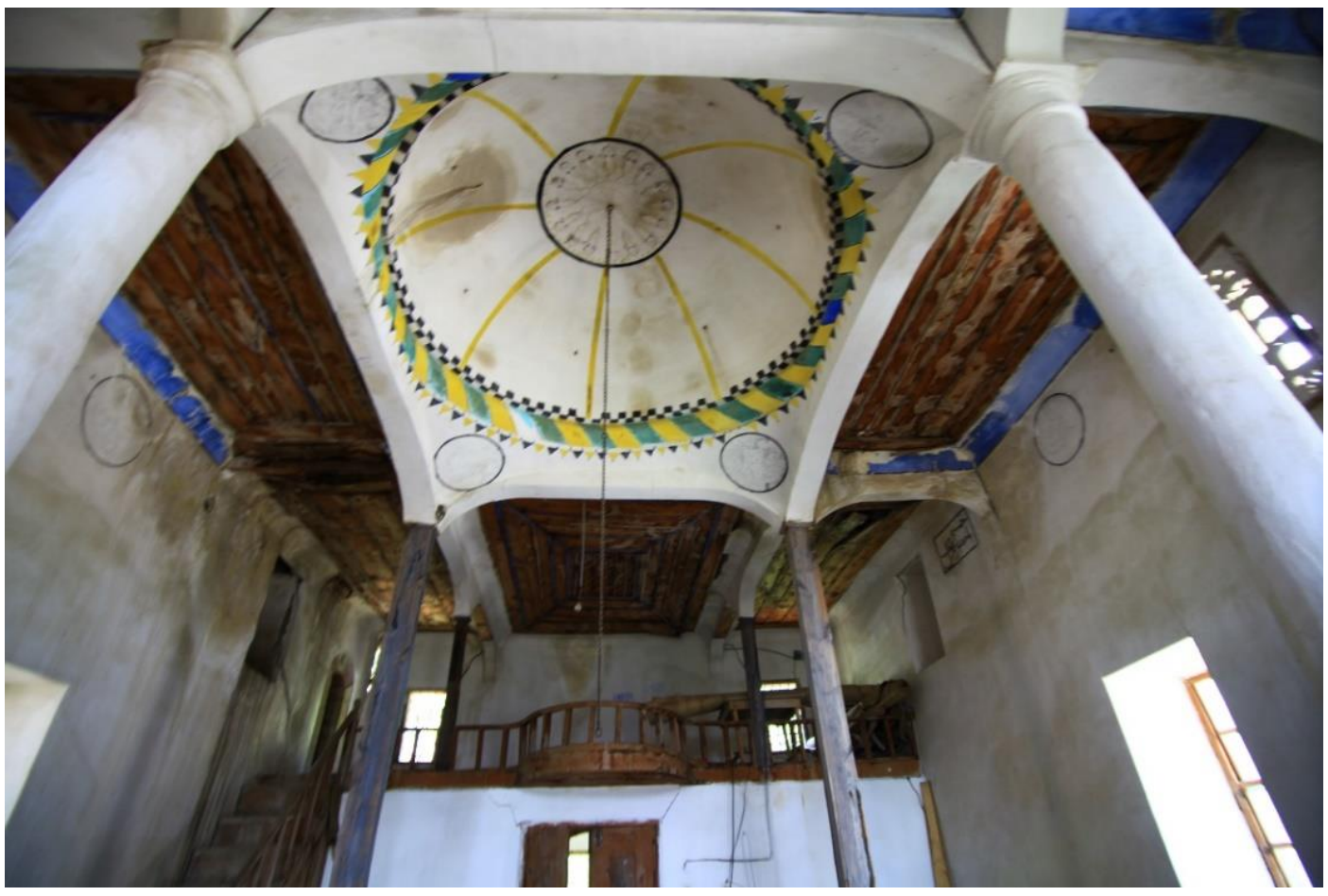

Fotoğraf 14. Üçköy Köyü Camii, düz ahşap tavan ve merkezde destekli bağdadi kubbe, Mayıs, 2018, Sabri Çiçekçi

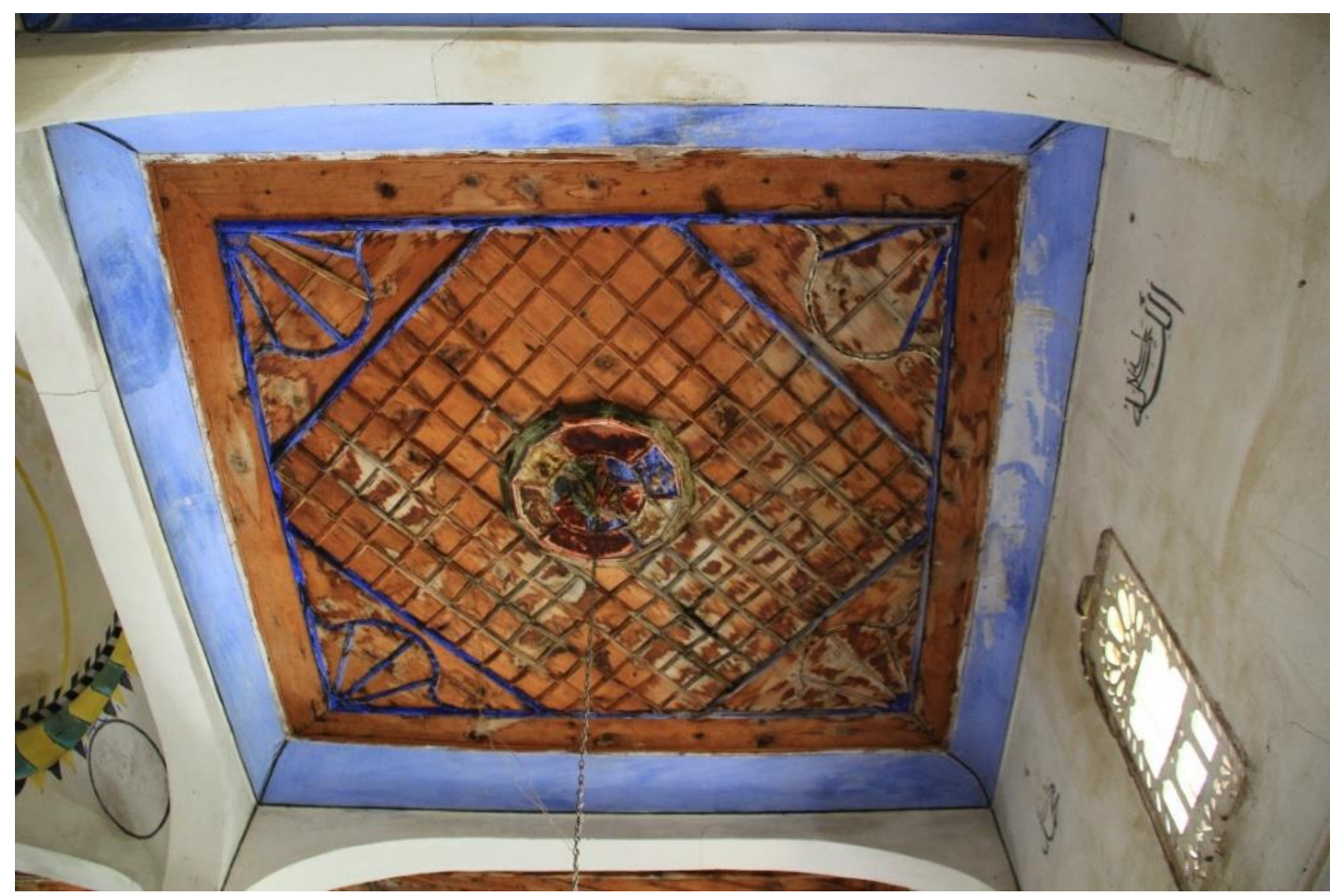

Fotoğraf 15. Üçköy Köyü Camii, mihrap önü bölümü tavan süslemesi, May1s, 2018, Sabri Çiçekçi 
Camide çıtakari süsleme ahşap minberde de karşımıza çıkmaktadır. Minberin mihrap tarafına bakan yüzü çıtakâri kare, dikdörtgen ve üçgenlerle süslenmiştir. Ayrıca bu yüzün ortasında iç içe geçmiş sekizgenlerden oluşan geometrik bir motif yer almaktadır (Fotoğraf 12).

Ahşap oyma teknikli bezemeler harime girişi sağlayan çift kanatlı kapıda görülmektedir. Ahşap kapı kanatlarına, etrafları ince iç ve dış bükey silmelerle çevrili üçer tane geometrik motif üst üste simetrik olarak yerleştirilmiştir. Geometrik motifler, ilk sırada düşey dikdörtgen, ikinci sırada kare ve üçüncü sırada yine düşey dikdörtgen şeklinde her bir kanatta sıralanmaktadır. Dikdörtgen şekilli motiflerin ortasında sekizgenler, sekizgenlerin ortasında ise iki ucunda stilize birer çiçek motifi tasvir edilen eşkenar dörtgen şekilli süslemeler yer almaktadır. Kare şekilli motiflerin tezyinatında doğu kanat ve batı kanat arasında fark vardır. Doğu kanatta kare şekilli motifin içerisinde sekizgen, sekizgenin ortasında iç içe geçmiş birkaç halka ve merkezde stilize bir çiçek motifi yer alırken, batı kanatta sekizgen şeklin içerisinde motif olmayışı bitirilememişlik hissi uyandırmaktadır (Fotoğraf 16).

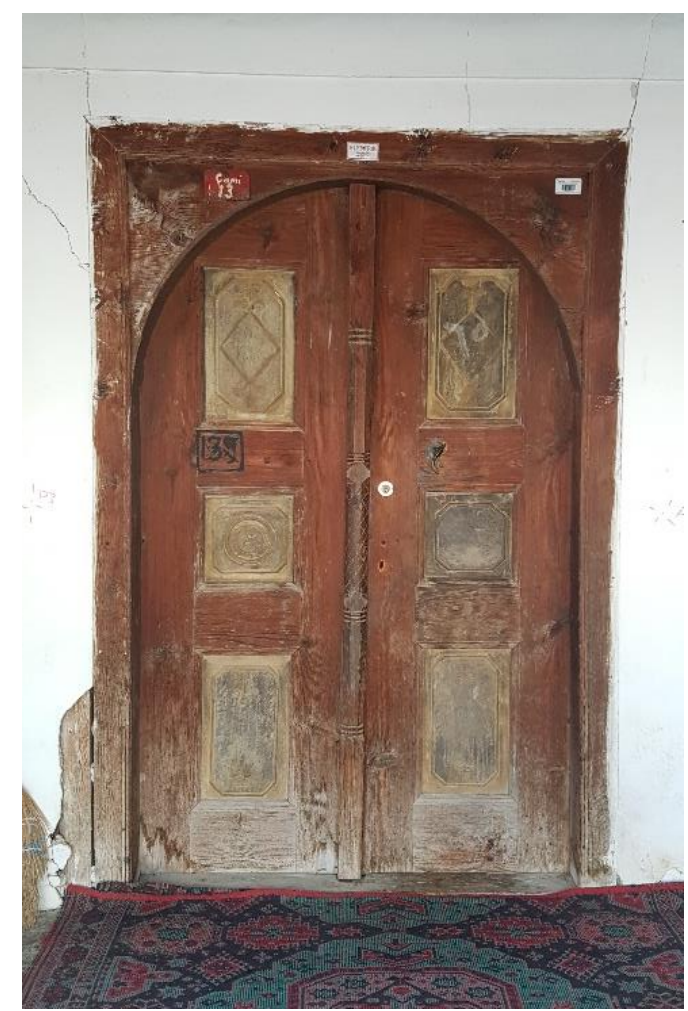

Fotoğraf 16. Üçköy Köyü Camii, harime giriş kapısı, Ekim, 2018, Çiğdem Karaçay

Harim duvarlarında, üst kat pencereler seviyesinde kalem issiyle yazılmış yazılar dikkati çekmektedir (Fotoğraf 6). Mihrabın üst kesiminde sol tarafta "Muhammed Aleyhi's - Selam" (Muhammed'e selam olsun), sağ tarafında "Allâh Celle Celâhülû" (Şanı yüce olan Allah); doğu duvarında, kuzeyden güneye doğru "İnnâ ve âlâ ve Münevviril'l - ehad" (Muhakkak ki biz Tek olan aydınlatıcının yolundayız), "Yâ Hazret - i Hüseyin" yazmaktadır. Kubbeyi taşıyan alçı sıvalı sütunlarda ise "Accilû bi’t - tevbeti gable’l - mevt” (Ölüm gelmeden önce tevbe için acele edin) yazmaktadir.

Alçı süsleme mihrapta ve üst kat pencerelerde görülmektedir. Mihrapta üstten dışbükey silme ile birbirine bağlanan köşe sütuncelerinin üst kısmı vazo şeklinde tertiplenmiştir. Doğu kısımdaki vazoda akant motifi bulunmaktadır. Mihrabın batısında yer alan sütünce de bu motif kırılmış olup mevcut değildir (Fotoğraf 9). Pencerelerde ise alçı şebekeler geometrik ve bitkisel 
kompozisyonlarla süslenmiş olup, dikdörtgen, yıldız, damla ve stilize yaprak motifleri kullanılmıştır. Bu alçı şebekeler harime varsıl bir görünüm kazandırmaktadır (Fotoğraf 6).

\section{KARŞILAŞTIRMA VE DEĞERLENDIRME}

Çorum merkeze bağlı Üçköy Köyü'nde bulunan ve korunması gerekli kültür varlığı olarak tescillenen Üçköy Köyü Camii, yerel mimari özellikler taşıyan basit kuruluşlu mimarisi ve süsleme programı açısından mütevazı üslubuyla Osmanlı Devrinin son dönem dini mimari örneklerindendir.

Küçük boyutlu bir yapı olan Üçköy Köyü Camii'nin en dikkat çeken kısmı, içerde, düz ahşap tavan ortasında bağdadi teknikle yapılmış kubbesidir. Türk mimarisinin başlica yap1 elemanlarından biri evrensel bir örtü öğesi olan kubbe olmuştur. Anadolu'da eski bir geçmişe sahip kubbe konstrüksiyonu, Osmanlı'nın merkezi mekân elde etme olgusu ile gelişerek, başka hiçbir mimari üslupta bulunmayan ve saf geometrisi (yarım küre kubbe) bozulmayan kubbeye boyutsal varyasyonlarla zengin bir mekân ve kütle biçimlendirme olanağı vermiştir. Osmanlı mimarisinde örtü öğesi olarak kubbenin kullanımı, kubbeli örtünün zengin çeşitlerinin yaratılmasına imkân tanımıştır (Kuban, 2016, ss. 459-462). Cami mimarisinin karakteristik bir öğesi olan kubbenin bağdadi teknikle örtü sisteminde kullanılması bu zengin çeşitlilik içerisinde bir yapı tekniği olarak karşımıza çıkmaktadır. Bağdadi, mimari bir terim olarak; "Ağaç direkler üzerine çakılmış çıtalara ya da kamışlara sıva vurularak yapılan duvar ya da tavan” yapı tekniğidir (Hasol, 2012, s. 61). Bu teknik Osmanlı'da dini mimari ile sivil mimaride önemli uygulama alanına sahiptir. Ahşap örtü sistemi kullanılan yapılarda görülen bağdadi teknik, cami mimarisinde kubbede karşımıza çıkmaktadır. Çatı içinde, çatı makasları arasına yerleştirilerek kubbe etrafının düz ahşap tavan ile örtülmesi en yaygın uygulama biçimi olmaktadır (Şahin, 2016, ss. 15-16). Bunun yanı sıra merkezdeki bağdadi kubbe etrafının düz ahşap tavan kullanılmadan, bağdadi tonozlarla kapatıldığı ya da birbirlerine kemerlerle bağlı bağdadi kubbelerle çok üniteli camiler Ege Bölgesi (Bayrakal, 2007, ss. 1-26) ve Doğu Karadeniz Bölgesi'nde (Şahin, 2016, s. 272) karşımıza çıkmaktadır. Ahşap strüktürlü ve bağdadi sıvalı kubbe, iç mekânın tamamını kaplayan bir örtü elemanı niteliğinde değil, çoğunlukla dikdörtgen harim kısmını örten ahşap tavanın merkezinde küçük simgesel bir kubbe niteliğindedir. Bu tip camilerde kubbe duvarlara oturmaz. İçerisinde düşey taşıyıcı eleman gerektiren geniş iç mekâna sahip camilerde de bu kubbe çoğunlukla taşıyıcılardan bağımsızdır (Tuluk-Durmuş, 2010, s. 206).

Çorum'da fazla yaygın olmamakla birlikte bağdadi kubbeli camiler görülmektedir. Çorum Ulu Camii'nde8 (19. yüzy1l), kare planlı harimin orta bölümü bağdadi büyük bir kubbe ile kubbenin dört tarafında diğer kısımlar ahşap tavanla örtülüdür. Bağdadi kubbe 12 ahşap sütun üzerine oturmaktadır. Kubbe ve ahşap tavan dışardan kırma çatı altına alınmıştır (Dündar, 2004, ss. 84101). Çorum merkezde bulunan bağdadi kubbeli bir diğer yap1 Kulaksız Camii'dir (19. yüzyıl). Kulaksız Camii'nde kare planlı harim bağdadi kubbe ile örtülmüştür. Kubbe birbirine basık kemerlerle bağlı on iki ahşap sütuna binmektedir. Harimin kubbeyle örtülü bölümün dişında kalan kısımlar dört yönde ahşap düz tavanla örtülmüştür. Yap1 dışarıdan kiremitli kırma çatı altına alınmıştır (Dündar, 2004, ss. 50-56). Çorum'da bağdadi kubbeli bir diğer cami İskilip ilçesinde bulunan Ulu Camii'dir (1841). Ahşap örtü sistemi içinde destekli bağdadi kubbe ahşap tavanın merkezine yerleştirilmiş, dıştan kiremit kaplı kırma çatı ile örtülmüştür (İlter, 1992, ss. 67-70). Çorum merkez ve ilçelerinde yer alan yukarıda bahsettiğimiz yapıların mimari ve süsleme

8 Çorum Ulu Camii'nin ilk inşası 13. yüzyılın sonlarına tarihlenmektedir. Ancak bu camiden günümüze hiçbir şey kalmamış, cami bugünkü şeklini 1810 ve 1911 yıllarındaki tamirlerde almıştır. Detaylı bilgi için bkz.: Dündar, 2004, 84-101. 
özellikleri göz önünde alındığında, Üçköy Köyü Camii’nin, Çorum'da bağdadi kubbeli camilerin basit ve mütevazı bir temsilcisi olduğu görülmektedir.

Kırma çatı içerisinde bağdadi kubbe uygulaması Çorum dışında farklı bölgelerde de karşımıza çıkmaktadır. Özellikle Doğu Karadeniz Bölgesi’nde Trabzon ilindeki camilerde bağdadi tekniğin farklı varyasyonları söz konusudur. En çok görülen uygulama, ahşap tavan ortasında desteksiz tek kubbenin görüldüğü plandır. Bu planda, ahşap tavanın ve kubbenin ağılığı beden duvarlarına bindirilir. Bu camilere, Sürmene Baştımar Mahallesi Camii (1859), Sürmene Balıklı Mahallesi Camii (1873), Arsin Işıklı Köyü Merkez Camii (1902), Of Saraçlı Köyü Yukarı Mahalle Camii (20. yy), Hayrat Kurtuluş Mahallesi Camii (1919-20), Of Ballıca Beldesi Büyük Mahallesi Camii (1942), Maçka Esiroğlu Beldesi Durali Camii (1949), Maçka Kaynarca Mahallesi Camii (1950), Of Ağaçseven Köyü Merkez Camii (1950), Beşikdüzü Dolanlı Köyü Camii (1955), Arsin Işıklı Köyü Yeni Camii (1956) ve Of Uğurlu Beldesi Yeni Camii (1967-72) örnek olarak verilebilir (Şahin, 2016, s. 251).

Birden fazla kubbenin yer aldığ1 örtü şeması, bu türün bir başka varyasyonu olup örnekler Trabzon'da karşımıza çıkmaktadır. Trabzon'un Araklı ilçesinde yer alan Merkez Camii (1902-03), Kalecik Mahallesi Camii (20.yy) ve Merkez Fatih Sultan Mehmet Camii (1951-52) ahşap strüktürlü ve bağdadi sıvalı, birden fazla kubbenin yer aldığı bir örtü şeması sergilemektedir (Tuluk-Durmuş, 2010, ss. 205-215).

Ahşap strüktürlü ve bağdadi sıvalı kubbeli örtü şeması sergileyen camiler, Doğu Karadeniz'de Giresun'da da görülmektedir. Bulancak Eski (Çarşı) Camii (1847), Hacı Hüseyin Camii (1861), Bulancak Şemseddin Mahallesi Camii (1896) ve Piraziz Gedikalizade Camii (1906), diştan kırma çatı, içten düz ahşap tavan ortasında bağdadi kubbe yerleştirilen örtü sistemine sahiptir. Giresun Görele Hasan Ağa Camii'nde (1907) ise tavan ve kubbenin ağırlı̆̆1 yanlarda duvarlara, ortada dört adet ahşap sütuna aktarıldığ1 destekli örtü sistemine sahiptir (Şahin, 2013, ss. 71-89). Doğu Karadeniz'de bağdadi kubbeli bir başka cami Samsun'un Bafra ilçesindedir. Bafra Tayyar Paşa Camii’nin (19. yüzyıl) örtü sistemi dıştan kırma çatı içerisine alınan bağdadi kubbelidir (Bayraktar, 2005, ss. 109-113). Artvin ve Rize'de yine plan kuruluşu itibariyle destekli veya desteksiz düz tavan ortasında kubbeli örtü ve genel uygulamanın birer çeşitlemesi olan örnekler sunmaktadır. Orta Karadeniz Bölgesi'nde Ordu ve Samsun illerinde bağdadi kubbeli yapılar görülmekle birlikte sayılarında azalma söz konusudur. Samsun'da bulunan bağdadi kubbeli camiler kare ve dikdörtgen harimde tek kubbeli plan şemaları ile küçük boyutlu eserlerdir (Şahin, 2016: ss. 252-255)

Bu tür yapılar Ege Bölgesi'nde de yoğun kullanım alanı bulmuştur. Ersoy (1990), Kırkağaç Çiftehanlar Camii'ni (1864-1865) incelediği makalesinde, bu tip kubbelerin ev, köşk, saray gibi sivil mimari eserlerde daha yaygın kullanım alanı bulduğunu belirtmekte ve 1635 tarihli Topkap1 Sarayı Revan Köşkü, 1643 tarihli Topkapı Sarayı Sepetçiler Köşkü ile yine 17. yüzyıldan Sultan Ahmet Camii ve Yeni Hünkâr Kasrını örnek olarak vermektedir. Bu planda, hafif olduğu için kubbeyi taşıyacak elemanlara gerek olmadığını, kubbelerin dekoratif öğeler olarak karşımıza çıktığını belirten Ersoy, Kırkağaç Çiftehanlar Camii'nin kubbesini, bu kubbelerin devamı niteliğinde olduğunu belirtmektedir. Kırkağaç Çiftehanlar Camii, ortada bağdadi bir kubbe ve bu kubbe ile beden duvarları arasında kalan bölümleri örten bağdadi tonoz parçalarından oluşan örtü sistemine sahip olması bakımından farklı bir uygulamaya işaret etmektedir (ss. 107-108). Benzer örtü sistemine sahip bir başka örnek İzmir’in Bergama ilçesinde Gökçebeyli beldesinde bulunan 19. yüzyıla ait camidir. Bağdadi tekniğin görüldüğü örtüde, merkezde altı desteğe oturan kubbe ve kubbeyi dört yönden kuşatan ahşap tonozlu örtü sistemi ile farklı, ahşap merkezi kubbenin çevresindeki tonoz parçaları açısından Çiftehanlar Camii'ne benzer bir uygulama söz 
konusudur (Bayrakal, 2007, ss. 1-26). Dolayısılla bu iki yapıda ahşap kubbeli camilerde genel bir uygulama olan kubbe ile harim duvarları arasında kalan alanların düz ahşap tavanla örtülmesinin farklı geliştiğini görmekteyiz.

Anadolu'da farklı bölgelerden örneklerini verdiğimiz bağdadi kubbeli bu yapılar, örtü sitemlerindeki üslup özellikleri açısından benzer özellikler göstermektedir. Ancak Çorum Üçköy Köyü Camii’nde olduğu gibi ahşap tavan ortasında destekli tek kubbenin yer aldığı plan tipi Doğu Karadeniz Bölgesi'ndeki yapılar arasında Giresun Görele Hasan Ağa Camii (1907), Trabzon'da, Çaykara Şahinkaya Köyü Gülveren Mahallesi Camii (1876-86) ve Beşikdüzü Türkelli Beldesi Merkez Camii'nde (1913) görülmektedir. Ege Bölgesi'nden benzer bir plan Turgutlu (Manisa) Irlamaz Köyü Camii'nde (19. yüzyıl) uygulanmıştır. Irlamaz Köyü Camii’nde merkezde dört sütuna oturan ahşaptan küçük bir kubbeye yer verilmiştir (Gürbıyık, 2016, ss. 146-162).

Bağdadi kubbeli örtü şemasına sahip camilerde dikkat çeken önemli bir husus, dış cephede olabildiğine sadelik hâkim iken iç mekânda yoğun bezemelerin görülmesidir. Ancak çalışmamıza konu Çorum Üçköy Köyü Camii tezyinat açısından dış cephede olduğu gibi iç mekânda da sade bir anlayışla tertiplenmiştir. Üçköy Köyü Camii'nde malzemeye göre ahşap, alçı ve kalem işi süslemeler görülmektedir.

Ahşap süsleme, harime girişi sağlayan kapı kanatları ile kubbe etrafında ve minberde çakma tekniğinde çıtalarla oluşturulan geometrik karakterli basit düzenlemeler olarak karşımıza çıkmaktadır.

Alçı süsleme, bağdadi kubbenin göbeğinde ve ikinci sıra pencerelerin iç mekâna açılan alçı şebekelerinde basit geometrik ve bitkisel motiflerle oluşturulan süslemeler şeklindedir. Alçı mihrap, köşe sütuncelerinin üst kısmında yer alan vazo ve akant motifi dışında sade bir anlayışla tertiplenmiştir. Ayrıca mihrap yivsiz istiridye kabuğu şeklini andıran tezyinatsız kavsarası ile Çorum'da çağdaşı olan birçok cami mihrabı ile benzerlik göstermektedir. Çakır Camii (19. yüzyıl), Kellegöz Camii (19. yüzyıl), Kulaksız Camii (19. yüzyıl) ve İnayetullah Camii'nin (20. yüzyıl başları) alçı mihrapları, kaş kemerli mihrap nişi ve dilimsiz istiridye kabuğu biçimindeki kavsaraları ile örnek olarak verilebilir.

Plan şeması açısından benzer özellikler gösteren camilerde yoğun bir şekilde yer alan kalem işi süslemeler, Üçköy Köyü Camii'nde bağdadi kubbe de görülmektedir. Merkezi kubbenin göbeğinde bulunan alçı madalyonun etrafındaki kalem işi süslemeler oldukça basit çizgilerden müteşekkil bir görünüm sunmaktadır. Sanatsal açıdan değeri olmayan bu süslemeler canlı renkleriyle dikkat çekmektedir. Ayrıca harim duvarlarında üst kat pencereler seviyesinde kalem işiyle yazılmış yazılar yer almaktadır. Bu süslemelerin sonradan yapılmış olması ya da var olan kalem işi nakışların zamanla silik ve soluk bir görünüm almasıyla, üzerlerinden yeni boyalarla gidilerek yenilenmiş olması muhtemeldir.

\section{1. Çorum Üçköy Köyü Camii'nin Tarihlendirilmesi}

Bugün Üçköy Köyü Camii'nde tarih veren iki kitabe bulunmaktadır. Bunlardan biri minare kaidesi üzerinde yer alan 1897 tarihli onarım kitabesidir. Diğeri taşınabilir kültür varlıkları kapsamında iki adet kitabeli şamdandır. İbadet ederken kullanılmak üzere hayırseverler tarafından camilere vakfedilen vakıf eserleri, kitabeleri dikkate alınarak bulundukları yapının inşa tarihi hakkında bizlere fikir vermektedir (Bozkurt, 2015, ss. 7-25). Ancak Üçköy Köyü Camii'nde bulunan vakıf şamdanlar, kitabelerine göre 1900 tarihli olup, yapının onarımından sonra camiye vakfedilmiştir. Kitabelerin dışında hurufat kayıtlarında 1844 tarihinde camiye imam atanmasına dair bir belge yer almaktadır. Ayrıca Anadolu'da bağdadi kubbeli yapıların 18. ve 19. 
yüzyıllarda yoğun olarak görülmesi ve Üçköy Köyü Camii'nin mihrap üslubunun 19. yüzyılda yakın çevrede inşa edilen dini mimari örneklerinde yaygın olarak görülmesi gibi sebeplerle camiyi, 19. yüzyılın ilk yarısına tarihlendirmenin uygun olacağını düşünüyoruz.

\section{2. Çorum Üçköy Köyü Camii Günümüzdeki Durumu}

Cami, 1897 tarihli kitabeyle tescillenen tamirinden sonra yenileme geçirmemiştir. Dolayısıyla yapida doğa koşullarının olumsuz etkisi görülmektedir. Çatı kaplaması bozulmuş, çatı elemanlarının su almasından dolayı yapıda özellikle ahşap öğeler büyük zarar görmüştür. Su ve nemden dolayı ahşap döşeme ve tavanda, kubbeyi taşıyan elemanlarda, ahşap mahfil katında pencere doğramalarında çürümeler vardır. Ayrıca cami iç ve dış sıvasında çatlaklar ve yer yer dökülmeler vardır.

\section{SONUC}

Çorum merkeze $40 \mathrm{~km}$. uzaklıkta bulunan ve bulunduğu köyün ismi ile bilinen Üçköy Köyü Camii; bütünüyle dikdörtgen planlı, moloz taş malzemeli, tek minareli, ahşap mahfili ve diştan kırma çatı, içten düz ahşap tavan ortasına bağdadi kubbe yerleştirilen örtü sistemi gibi genel mimari özelliklere sahip Anadolu köy camilerinin sade bir örneğidir. Bulunduğu köyün ihtiyac1 için küçük boyutlarda yapılan cami, süsleme programı açısından da mütevazı bir üslup sergilemektedir. Çorum'da fazla yaygın olmamakla birlikte bağdadi kubbeli camiler görülmektedir. Bu camilere örnek olarak Çorum Ulu Camii, Çorum Kulaksız Camii ve İskilip Ulu Camii verilebilir. Çorum dışında Ege Bölgesi, Doğu Karadeniz Bölgesi ve Marmara Bölgesi'nde de bağdadi kubbeli yapılar görülmektedir. Anadolu'da farklı bölgelerde bulunan bağdadi kubbeli bu yapılar, örtü sitemlerindeki üslup özellikleri açısından benzer özellikler göstermektedir. Bağdadi kubbeli örtü şemasına sahip camilerde dikkat çeken husus, dış cephede olabildiğine sadelik hâkim iken iç mekânda yoğun bezemelerin görülmesidir. Çorum Üçköy Köyü Camii ise tezyinat açısından dış cephede olduğu gibi iç mekânda da sade bir anlayışla tertiplenen, Osmanlı Devrinin son dönem dini mimari örneklerindendir. Cami, 1897 tarihli kitabeyle tescillenen tamirinden sonra yenileme geçirmemiştir. Dolayısıyla yapıda doğa koşullarının olumsuz etkisi görülmektedir. Bağdadi kubbeli camilerin Orta Karadeniz Bölgesi'nde sade bir örneğini teşkil eden ve yıllarca köy halkına hizmet eden tarihi caminin restore edilerek gelecek nesillere aktarılması hususu en büyük temennimizdir.

\section{KAYNAKÇA}

Bayrakal, S. (2007, Ekim). Merkezi plan tasarımı ve malzeme özellikleriyle ilginç bir örnek: Gökçebeyli (Bergama) Merkez Camii ve restorasyon önerileri. Sanat Tarihi Dergisi, 16(2), 126. Erişim adresi: https://dergipark.org.tr/en/download/article-file/152489

Bayraktar, S. (2005). Samsun ve ilçelerinde Türk mimari eserleri. (Yayımlanmamış doktora tezi). Atatürk Üniversitesi Sosyal Bilimler Enstitüsü, Erzurum.

Bozkurt, T. (2015). Konya - Hatunsaray (Lystra) ve çevresindeki cami ve mescitler. Ankara Üniversitesi Dil ve Tarih - Coğrafya Fakültesi Dergisi, 55(1), 1-54. Erişim adresi: http://dtcfdergisi.ankara.edu.tr/index.php/dtcf/article/view/52

Çiçekçi, S. (Mayıs, 2018). Sabri Çiçekçi’nin fotoğrafı, Kişisel Arşiv.

Dündar, A. (2004). Çorum cami ve mescitleri. Ankara: Aydan Web Ofset.

Ersoy, İ. (1990). Kırkağaç Çiftehanlar Camii. Arkeoloji-Sanat Tarihi Dergisi, 5, 103-115. Erişim adresi: https://dergipark.org.tr/tr/download/article-file/152241 
Gürbıyık, C. (2016, Eylül). Turgutlu Irlamaz Köyü Camii. CBÜ Sosyal Bilimler Dergisi, 14(3), 146162. doi: $10.18026 /$ cbusos.07482.

Hasol, D. (2012). Ansiklopedik mimarlık sözlüğü. İstanbul: Yem Yayın.

İlter, F. (1992). Bir Anadolu kenti İskilip. Ankara: Türk Tarih Kurumu.

Kuban, D. (2016). Osmanlı mimarisi. İstanbul: Yem Yayın.

Şahin, M. (2013). Giresun ilindeki bağdadi kubbeli camiler. TÜBA-KED (Türkiye Bilimler Akademisi Kültür Envanteri Dergisi), 11, 71-89.

Şahin, M. (2016). Giresun ve Trabzon illerindeki bağdadi kubbeli camiler. (Yayımlanmamış Yüksek Lisans Tezi). Gazi Üniversitesi Sosyal Bilimler Enstitüsü, Ankara.

Tuluk, Ö.İ ve Durmuş, S. (2010, Aralık). Araklı'nın çok kubbeli camileri üzerine birkaç not. Arredamento Mimarlı, 110-116.

Vakıflar Genel Müdürlüğü. (2002, Ocak). Üçköy Köyü Camii’nin çizimi (Belge No: 190001010OC001) Vakıflar Genel Müdürlüğü Arşivi. 


\section{SUMMARY}

The present article aims to introduce the architectural and ornamental characteristics of Üçköy Village Mosque, which is located $40 \mathrm{~km}$. from Çorum downtown area and known by the name of the village it stands, by employing Art History methodology, and to identify the standing of the structure within Anatolian Turkish architecture through comparison with similar examples. In this context, Üçköy Village Mosque has been surveyed on-site after acquiring necessary permits from Çorum Governor's Office. The mosque is located within a courtyard at the center of the village. There is no construction epigraph on the structure. The restoration epigraph on the minaret pedestal indicates that the mosque was maintained in 1897 by Ali Pasha. Constructed on slightly inclined terrain, the mosque features a longitudinal rectangle plan with overall dimensions of $8.90 \mathrm{~m} . \times 13.90 \mathrm{~m}$. in north-south direction. The narthex is located to the north and the minaret stands west of the narthex. The interior is formed by wooden flat slab ceiling with a dome at the center constructed with lath and plaster technique. The upper floor of the narthex is arranged as women's gathering place. The foundation and the walls of the structure are made of rubble stone, while the wall corners are made of cut stone. The facades are plastered, however the plaster has shed at some spots, and there are some recently plastered sites. The structure has been erected with pantile hipped roof. The minaret is at northwest corner of the prayer place. The square planned minaret pedestal made of cut stone is level with the prayer place wall and is adjacent to the façade. The structure presents plain exterior visual features. The windows are arranged as two rows. The number of windows is irregular. The northern façade of the structure comprises of the narthex featuring transversal rectangle plan extending in east-west direction. The prayer place is accessible from the courtyard via semicircular arched and double winged door at the axis of the niche. The interior space is illuminated by total of 15 windows one on top of the other and opening to facades. The prayer place is covered with wooden flat slab ceiling and a lathand-plaster dome supported on four columns at the center. Within the entire wooden covering system, the lath-and-plaster dome is located at the center of the wooden ceiling. The portions of prayer place outside the dome-covered section are covered with flat slab ceiling in all four directions. The northern side of prayer place is arranged as the gathering place. The wooden gathering place floor is accessible via 11 stepped wooden staircase located north-west of the prayer place. The niche is positioned on the axis of the northern entrance at the center of the Kiblah wall. The pulpit is located at the western edge of the southern façade. The ambo with wooden railing constructed adjacent to the wall is located at the eastern edge of the southern façade. The ornamentation program of Üçköy Village Mosque is plain in general. It is possible to review the ornamentations of the Mosque in three groups as wooden, hand-drawn and gypsery ornaments. The ornamentations concentrate at the ceiling of prayer place. The hand-drawn and gypsum ornamentation at the lath-and-plaster dome, and the ornamentations made using "çıtakâri" technique at the rest of the ceiling stand out on the ceiling of the prayer place. "Çıtakari" ornamentations appear also on the wooden pulpit within the mosque. Ornaments made using wooden engraving technique appear on double-winged door granting access to the prayer place. The hand-drawn inscriptions created on the prayer place walls at the level of upper floor windows are also striking. The gypsum ornaments are rather observed at the niche and at the upper floor windows. When considered in terms of architectural and ornamental characteristics, it is possible to state that Çorum Üçköy Village Mosque is a plain example of the Anatolian rural mosques, with small-sized construction based on the demands of the village presenting a humble style in terms of ornamental program. The lath and plaster domed mosques can be encountered in Çorum, although not so frequently. Çorum Grand Mosque, Kulaksız Mosque, İskilip Grand Mosque can be named as examples for such mosques. Apart from Çorum, the lath-and-plaster domed 
structures are observed also in Aegean Region, Eastern Black Sea Region and Marmara Region. Such lath-and-plaster domed structures, which are encountered in different regions throughout Anatolia, present similar characteristics in terms of the stylish features at the cover systems. A striking aspect that draws attention at the mosques with lath-and-plaster domed covering schematics is that while the exterior façade is as plain as possible, intensive ornamentation are observed at the interior space. Çorum Üçköy Village Mosque of interest, however, has been organized with a simplistic approach in terms of ornamentation not only at the exterior façade, but also at the interior space. From early 19th Century, Çorum Üçköy Village Mosque has not been subjected to any restoration efforts after the repairs registered with the inscriptions dating back to 1897. Therefore, the negative impact of the nature is visible on the structure. It is our greatest desire to restore this historic mosque, which presents a plain example of lath-and-plaster domed mosques in Central Black Sea Region and which served to the village folk for years, thus preserve this historic structure for future generations. 